\title{
Optimal selection of parameters in CNC end milling of Al 7075 T6 alloy by TBLO
}

\author{
Fauzia Siddiqui*, Paramjit Thakur ${ }^{\#}$ \\ *Department of Mechanical Engineering, Jaipur Engineering College \& Research Centre (JECRC), \\ Rajasthan, India \\ \#Department of Mechanical Engineering, Saraswati College of Engineering (SCOE), Navi Mumbai, \\ India
}

(Received 21 October 2018; accepted 29 December 2018)

https://doi.org/10.36224/ijes.110405

\begin{abstract}
Al 7075 T6 is one of the highest strength aluminum alloys in 7000 series family which is used in highly stressed structural parts of aircrafts. The high surface roughness lowers the fatigue resistance and also affects the quality of the parts. Hence, this work deals with the application of teaching learning based optimization to minimize the roughness in the CNC end milling process. Here, taguchi L9 orthogonal array is used as experimental design. The depth of cut, feed and speed are used as control factors with three levels each and roughness as the response. The regression model was developed to find the effect of process parameters on response. The regression model was used by Teaching Learning Based Optimization (TLBO) algorithm and optimum process parameters were obtained. The optimal process parameters obtained by TLBO gave $60 \%$ reduction in roughness as compared to that given by initial setting of parameters used for machining of this material.
\end{abstract}

Keywords: TLBO, Al 7075 T6, optimization, milling

\section{Introduction}

Al 7075 T6 is one of the highest strength aluminum alloys in 7000 series family which is used in highly stressed structural parts of aircrafts [1]. The high surface roughness lowers the fatigue resistance and also affects the quality of the parts. The high roughness act as minute notches and induces the stress concentration. When such component is used in the application undergoing fluctuating stresses, the material may fail to its earliest. Hence, low surface roughness is needed to improve the life of this material [2]. In past many authors have used taguchi method for optimization of parameters, but it cannot handle complex problems [3]. Hence, this work has moved towards the metaheuristic algorithm to obtain the optimal process parameters. The optimal selection of process parameter in CNC cutting of various materials is done by many researchers which involved application of non-traditional optimization techniques like SA, GA, PSO, Firefly algorithm, Blackhole, Biogeography, etc. [4-7] All these evolutionary algorithms involve algorithm parameters which need to be finetuned to obtain the better results. The teaching learning based optimization (TLBO) technique doesn't involve any algorithm specific parameter hence it is easy to apply with very less computation time (Rao et al 2011). Hence this work deals with application of teaching learning based optimization (TLBO) in optimal selection of process parameters in milling of Al 7075 t6 alloy.

\footnotetext{
${ }^{*}$ Corresponding author

Email address: fauzia.hoda@gmail.com (Fauzia Siddiqui)

ISSN 0976 - 6693. (C2019 SCMR All rights reserved.
} 


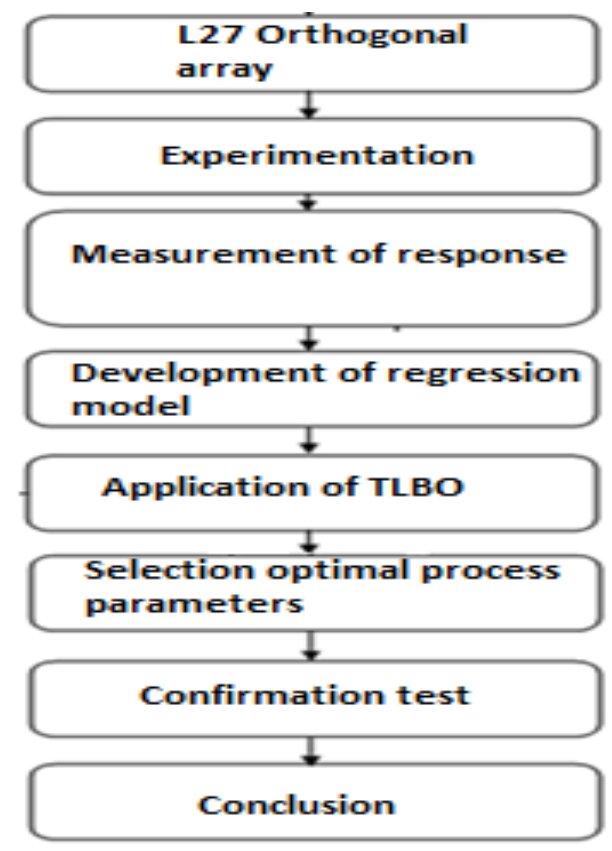

Figure 1: Overall methodology

\section{Taguchi DOE and experimentation}

In this work the Taguchi DOE is used to lessen the number of experimentation and to make the system robust. The L6 orthogonal array is used and the roughness is measured for each setting. The computer numerically controlled machines are widely used in industries, fully controlled with minimum human intervention to increase the productivity and improve the quality of machined parts. Among the other milling techniques, end milling is one of the vital operations for obtaining the ground finish. In this paper Vertical Milling Centre (Makino S33) is used for experimentation. The $16 \mathrm{~mm}$ diameter end milling cutter of ISCAR make was used for machining. The machining parameters were selected on the basis of various trial runs by checking their effect on Surface Roughness. The input process parameters taken in consideration are speed, feed and depth of cut. The designations of inserts used for experimentation in terms of their nose radius are R39011 T3 12-PM. The mitutoya surface roughness tester: Surftest SJ- 210 series was used to measure Ra values of surface roughness. The machining parameters and levels are shown in Table 1.

Table 1: Control factors and levels

\begin{tabular}{clccc}
\hline $\begin{array}{c}\text { Symbo } \\
\mathbf{l}\end{array}$ & \multicolumn{1}{c}{ Parameters } & Level1 & $\begin{array}{c}\text { Level } \\
\mathbf{2}\end{array}$ & $\begin{array}{c}\text { Leve } \\
\mathbf{1 3}\end{array}$ \\
\hline $\mathbf{A}$ & Speed (r.p.m) & 6000 & 8000 & 1000 \\
$\mathbf{B}$ & Feed (mm/rev) & 0.05 & 0.10 & 0 \\
$\mathbf{C}$ & $\begin{array}{l}\text { Depth of cut } \\
(\mathrm{mm})\end{array}$ & 0.1 & 0.2 & 0.15 \\
& & & & 0.3 \\
\hline
\end{tabular}


Table 2: Experimentation and measurement of roughness

\begin{tabular}{lllll}
\hline $\begin{array}{l}\text { Sr } \\
\text { no }\end{array}$ & $\begin{array}{l}\text { Speed } \\
(\text { r.p.m) }\end{array}$ & $\begin{array}{l}\text { Feed } \\
(\mathbf{m m} / \mathbf{r e v})\end{array}$ & $\begin{array}{l}\text { Depth of } \\
\text { cut }(\mathbf{m m})\end{array}$ & Ra \\
\hline $\mathbf{1}$ & 1 & 1 & 1 & 0.32 \\
$\mathbf{2}$ & 1 & 2 & 2 & 0.31 \\
$\mathbf{3}$ & 1 & 3 & 3 & 0.39 \\
$\mathbf{4}$ & 2 & 1 & 3 & 0.18 \\
$\mathbf{5}$ & 2 & 2 & 2 & 0.39 \\
$\mathbf{6}$ & 2 & 3 & 1 & 0.35 \\
$\mathbf{7}$ & 3 & 1 & 3 & 0.42 \\
$\mathbf{8}$ & 3 & 2 & 1 & 0.49 \\
$\mathbf{9}$ & 3 & 3 & 2 & 0.5 \\
\hline
\end{tabular}

Regression equation: $\mathrm{Ra}=0.0992+0.00005 * \mathbf{X}_{1}+0.000029 * \mathbf{X}_{2}-0.000014 * \mathbf{X}_{3}$

\section{Teaching learning based optimization}

The Teaching learning based optimization (TLBO) was proposed by Rao et al (2011). The TLBO mimics the process of teaching and learning between the students and teachers inside a classroom. In The Teaching learning based optimization a bunch of learners resembles the population. The various factors used in experimentation are considered as subjects offered to the students (learners) and the results of the learners resemble the fitness value of the given problem. In the complete population, teacher is the best solution. The Teaching learning based optimization (TLBO) technique is divided in two phases: Teachers phase and learners phase which is explained further.

\subsection{Teacher Phase}

In this phase the students learn from the teacher and the teacher tries to increase the mean result of the learners. consider, at any iteration $i, m$ : number of factors (subjects), $n$ : number of learners (size of the population, $\mathrm{k}=1,2, \ldots, \mathrm{n}$ ), $\mathrm{M}_{\mathrm{j}, \mathrm{i}}$ :The learners mean result in a given subject $(j=1,2, \ldots, m)$. The best result in a given population is considered to be a teacher as the teacher is the most learned person. The difference between the mean result of each subject and that of a teacher is given by equation 2 .

Difference $\operatorname{Mean}_{\mathrm{j} k \mathrm{i}}=\mathrm{r}_{\mathrm{i}}\left(\mathrm{X}_{\mathrm{jkbesti}}-\mathrm{T}_{\mathrm{F}} * \mathrm{M}_{\mathrm{ji}}\right)$

$\mathrm{X}_{\mathrm{jkbesti}}$ is the best result of the population considered to be the teacher, $\mathrm{r}_{\mathrm{i}}$ is random number and $\mathrm{T}_{\mathrm{F}}$ is the teaching factor whose value can be either 1 or 2 .

$\mathrm{X}_{\mathrm{j}, \mathrm{k}, \mathrm{i}}^{\prime}=\mathrm{X}_{\mathrm{j}, \mathrm{k}, \mathrm{i}}+$ Difference $_{\mathrm{Mean}_{\mathrm{j}, \mathrm{k}, \mathrm{i}}}$

Where $\mathrm{X}_{\mathrm{j}, \mathrm{k}, \mathrm{i}}$ is the new value of $\mathrm{X}_{\mathrm{j}, \mathrm{k}, \mathrm{i}}$ and it is accepted if it is better than the initial result. 


\subsection{Learner Phase}

In this phase the learners increase their knowledge by randomly interacting with the other learners. A learner learns new things if the other learner has more knowledge than him or her. Considering a population size of ' $n$ ', the learning phenomenon of this phase is explained below.

Randomly select two learners $\mathrm{P}$ and $\mathrm{Q}$ such that $\mathrm{X}_{\text {total-P,i }}^{\prime} \neq \mathrm{X}_{\text {total-Q,i }}^{\prime}$ (where, $\mathrm{X}_{\text {total-P,i }}^{\prime}$ and $\mathrm{X}_{\text {total- }}^{\prime} \mathrm{Q}_{\mathrm{i}}$ are the updated function values of $\mathrm{X}_{\text {total-P,i }}$ and $\mathrm{X}_{\text {total-Q,i }}$ of $\mathrm{P}$ and $\mathrm{Q}$, respectively, at the end of teacher phase)

$\mathrm{X}^{\prime \prime}{ }_{\mathrm{j}, \mathrm{P}, \mathrm{i}}=\mathrm{X}^{\prime}{ }_{\mathrm{j}, \mathrm{P}, \mathrm{i}}+\mathrm{r}_{\mathrm{i}}\left(\mathrm{X}_{\mathrm{j}, \mathrm{P}, \mathrm{i}}-\mathrm{X}^{\prime}{ }_{\mathrm{j}, \mathrm{Q}, \mathrm{i}}\right)$, If $\mathrm{X}_{\text {total-P,i }}^{\prime}<\mathrm{X}_{\text {total-Q,i }}^{\prime}$

$\mathrm{X}_{\mathrm{j}, \mathrm{P}, \mathrm{i}}^{\prime \prime}=\mathrm{X}_{\mathrm{j}, \mathrm{P}, \mathrm{i}}^{\prime}+\mathrm{r}_{\mathrm{i}}\left(\mathrm{X}_{\mathrm{j}, \mathrm{Q}, \mathrm{i}}^{\prime}-\mathrm{X}_{\mathrm{j}, \mathrm{P}, \mathrm{i}}^{\prime}\right)$, If $\mathrm{X}_{\text {total-Q,i }}^{\prime}<\mathrm{X}_{\text {total-P,i }}^{\prime}$

$\mathrm{X}_{\mathrm{j}, \mathrm{P}, \mathrm{i}}$ is accepted if it gives a better function value. The Eqn. (4) and (5) are for minimization problems. In the case of maximization problem, the Equations (5) and (6) are used.

$X^{\prime \prime}{ }_{j, P, i}=X^{\prime}{ }_{j, P, i}+r_{i}\left(X^{\prime}{ }_{j, P, i}-X^{\prime}{ }_{j, Q, i}\right)$, If $X_{\text {total-Q, }}^{\prime}<X^{\prime}{ }_{\text {total-P,i }}$

$\mathrm{X}_{\mathrm{j}, \mathrm{P}, \mathrm{i}}^{\prime \prime}=\mathrm{X}^{\prime}{ }_{\mathrm{j}, \mathrm{P}, \mathrm{i}}+\mathrm{r}_{\mathrm{i}}\left(\mathrm{X}_{\mathrm{j}, \mathrm{Q}, \mathrm{i}}^{\prime}-\mathrm{X}_{\mathrm{j}, \mathrm{P}, \mathrm{i}}^{\prime}\right)$, If $\mathrm{X}_{\text {total-P,i }}^{\prime}<\mathrm{X}_{\text {total-Q,i }}^{\prime}$

Table 3: Confirmation test

\begin{tabular}{cccc}
\hline & $\begin{array}{c}\text { Initial } \\
\text { machining }\end{array}$ & TLBO & Improvement \\
\hline Setting level & A1B3C2 & A2B3C2 & ----- \\
Surface & 0.51 & 0.20 & $60 \%$ \\
roughness & & & \\
\hline
\end{tabular}

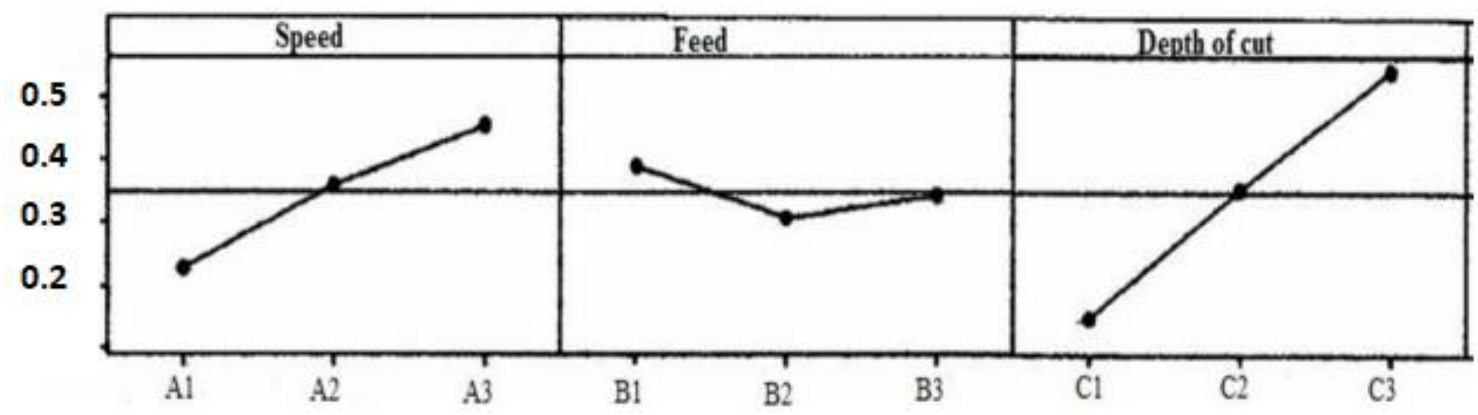

Figure 2: Effect of parameters on roughness

\section{Results and conclusion}

This work dealt with the application of teaching learning based optimization in finding the optimal process parameter in CNC end milling of AL 7075 t6 alloy. The taguchi L9 orthogonal array is used for experimental design and the mathematical model for TLBO is obtained by regression analysis. The initial setting of parameters used in industry for machining $\mathrm{Al} 7075 \mathrm{~T} 6$ alloy is $\mathrm{A} 1 \mathrm{~B} 3 \mathrm{C} 2$ which gave the roughness of $0.51 \mu \mathrm{m}$. The optimal process parameter given by TLBO is $\mathrm{A} 2 \mathrm{~B} 3 \mathrm{C} 2$ with the roughness of $0.20 \mu \mathrm{m}$. The application of TLBO gave an improvement of $60 \%$ in the surface roughness as compared to 
the initial process parameters as illustrated in Table 3. Also, the effect plot of parameters versus roughness is illustrated in Fig. 2. According to the plot, the roughness increased with the increase in the levels of speed and feed. And, in case of feed rate, initially the roughness decreased with the increase in the level and then there was slight increment in the roughness with the increase in feed rate. This work minimized the roughness in milling of Al 7075 T6 alloy and it will solve the problem of fatigue failure of this material to the greater extent.

\section{References}

[1] D.L DuQuesnay, P.R. Underhill and H.J. Britt, Fatigue crack growth from corrosion damage in 7075-T651 aluminium alloy under aircraft loading. International Journal of Fatigue 2003, 25, 371-377

[2] M. Suraratchai, J. Limido, C. Mabru and R. Chieragatti, Modelling the influence of machined surface roughness on the fatigue life of aluminium alloy. International Journal of Fatigue 2008, 30, 2119-2126

[3] J.A. Ghani, I.A. Choudhury and H.H. Hassan, Application of Taguchi method in the optimization of end milling parameters. Journal of Materials Processing Technology 2004, $145,84-92$

[4] N. Yusup, A.M. Zain and S. Z. M. Hashim, Evolutionary techniques in optimizing machining parameters: Review andrecent applications (2007-2011), Expert Systems with Applications 2012, 39, 9909-9927

[5] J. Zhou, J. Ren, C. Yao, Multi-objective optimization of multi-axis ball-end milling Inconel 718 via grey relational analysis coupled with RBF neural network and PSO algorithm. Measurement 2017, 271-285

[6] R. Yildiz, A new hybrid differential evolution algorithm for the selection of optimal machining parameters in milling operations. Applied Soft Computing 2013, 1561-1566

[7] R. Yildiz, A comparative study of population-based optimization algorithms for turning operations. Information Sciences 2012, 25, 81-88

[8] P.J. Ross, Taguchi Techniques for Quality Engineering, Tata McGraw-Hill ,1996 